
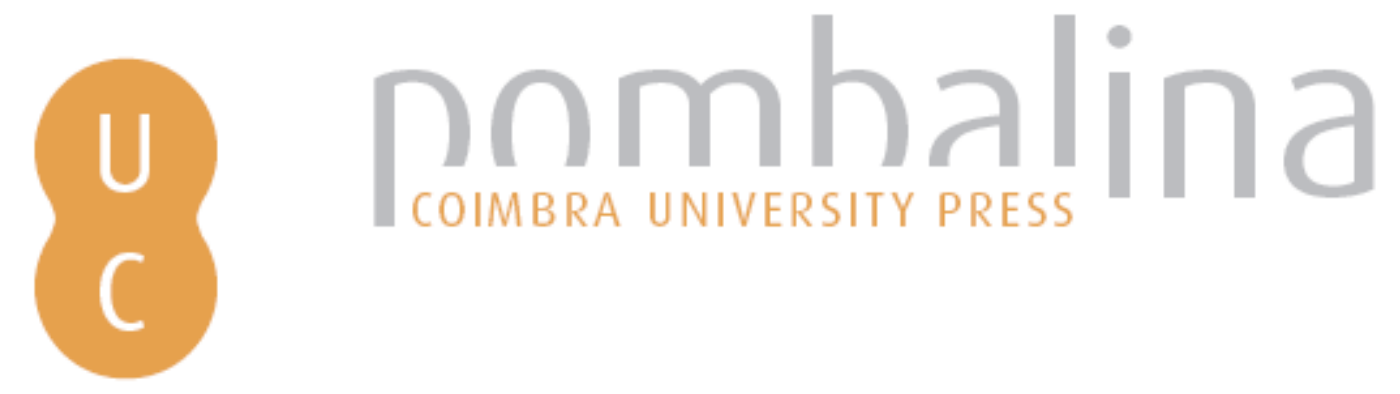

D. Pedro de Barcelos e a representação do passado lbérico

Autor(es): $\quad$ Ferreira, Maria do Rosário

Publicado por: Imprensa da Universidade de Coimbra

URL

persistente: $\quad$ URI:http://hdl.handle.net/10316.2/31561

DOI: $\quad$ DOI:http://dx.doi.org/10.14195/978-989-26-0405-3_5

Accessed : $\quad$ 26-Apr-2023 04:33:38

A navegação consulta e descarregamento dos títulos inseridos nas Bibliotecas Digitais UC Digitalis, UC Pombalina e UC Impactum, pressupõem a aceitação plena e sem reservas dos Termos e Condições de Uso destas Bibliotecas Digitais, disponíveis em https://digitalis.uc.pt/pt-pt/termos.

Conforme exposto nos referidos Termos e Condições de Uso, o descarregamento de títulos de acesso restrito requer uma licença válida de autorização devendo o utilizador aceder ao(s) documento(s) a partir de um endereço de IP da instituição detentora da supramencionada licença.

Ao utilizador é apenas permitido o descarregamento para uso pessoal, pelo que o emprego do(s) título(s) descarregado(s) para outro fim, designadamente comercial, carece de autorização do respetivo autor ou editor da obra.

Na medida em que todas as obras da UC Digitalis se encontram protegidas pelo Código do Direito de Autor e Direitos Conexos e demais legislação aplicável, toda a cópia, parcial ou total, deste documento, nos casos em que é legalmente admitida, deverá conter ou fazer-se acompanhar por este aviso.

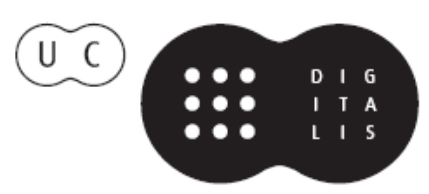


Maria do Rosário Ferreira

Coordenaçáo

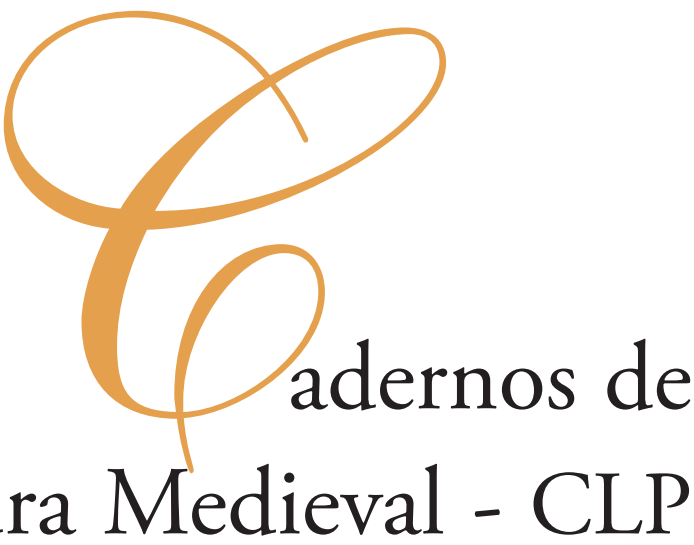

O Contexto Hispânico da Historiografia Portuguesa nos Séculos XIII e XIV

Em mémoria de Diego Catalán 
Maria do Rosário Ferreira

Faculdade de Letras da Universidade de Coimbra; Seminário Medieval de Literatura, Pensamento e Sociedade (IF-FLUP/FCT); Centro de Literatura Portuguesa (CLP-FLUC/FCT).

\section{PEDRO DE BARCELOS \\ E A REPRESENTAÇÃO DO PASSADO IBÉRICO}

A obra do Conde: breve ponto da questáo

D. Pedro Afonso, Conde de Barcelos, filho primogénito bastardo de El-Rei D. Dinis de Portugal, é das figuras a um tempo mais ilustres e mais obscuras da cultura medieval portuguesa. Foi-lhe há muito reconhecida a paternidade de duas extensas e relevantes compilaçóes: um nobiliário ${ }^{1}$, que influenciou de forma decisiva a produção genealógica peninsular dos séculos seguintes, e um cancioneiro trovadores $\mathrm{co}^{2}$, que permitiu a preservação do acervo poético da manifestação lírica cortês galego-portuguesa, então já em declínio. Obras nascidas de uma actividade de recolha a que os eruditos e estudiosos não parecem ter dado importância suficiente para se interrogarem sobre o sentido que fazia, ou poderia fazer, um tal afã compilatório em âmbito aristocrático peninsular ao avizinharem-se os meados do século XIV.

$\mathrm{O}$ ano de 1951 veio mudar definitivamente o perfil autoral do Conde de Barcelos, trazendo-o à ribalta da produção historiográfica medieval hispânica. Com efeito, Luís Filipe Lindley Cintra defendeu entâo ser a Crónica de 1344 uma obra com redacção primitiva em Português, tendo mostrado, além disso, que o seu autor não poderia ter sido senão o Conde de Barcelos ${ }^{3}$. Porém, o texto original dessa obra estava perdido, dele sobrevivendo apenas uma tradução castelhana, incompleta, em manuscrito do século $\mathrm{XV}^{4}$.

${ }^{1}$ O Livro de Linhagens, ed. Mattoso (1980).

2 O Livro das Cantigas, deixado em testamento pelo Conde de Barcelos a Afonso XI de Castela e entretanto perdido, mas que terá servido de base às cópias renascentistas de Angelo Colocci (respectivamente o Cancioneiro da Biblioteca Nacional, antes Colocci-Brancuti, e o Cancioneiro da Biblioteca Vaticana). D. Pedro Afonso é autor de algumas das derradeiras composiçóes trovadorescas que aí figuram.

${ }^{3}$ Ver Cintra (1951: CXXVII-CXC).

${ }^{4}$ Trata-se do ms. M, 2656 da Biblioteca Universitária de Salamanca, com 338 fólios; os foll. 104r-134v do ms. E, \&-II-i da Biblioteca de El Escorial, preservam também um fragmento em castelhano da obra. Para uma 
$\mathrm{Na}$ ausência de um testemunho português da versão primitiva, Cintra optou por dar a conhecer, na sua monumental edição crítica intitulada Crónica Geral de Espanha de $1344^{5}$, o texto português de uma refundição anónima, redigida circa $1400^{6}$, que não corresponde na realidade à crónica do Conde. A refundição substitui toda a parte inicial do texto atribuível a D. Pedro, que não assenta na progressão cronológica linear típica de anais e crónicas mas numa sucessão de listas de matriz genealógica ${ }^{7}$, por uma versão muito distinta, compatibilizada com a tradição da Estoria de Espanha ${ }^{8}$; e reescreve sem grandes modificações narrativas (o que não é equivalente a sem alterações de sentido ${ }^{9}$ ) o remanescente da obra, que na redacção original se filiava já na escola alfonsina ${ }^{10}$.

Em 1970, Diego Catalán e Maria Soledad de Andrés vêm remediar parcialmente este equívoco, ao darem a público o texto da tradução castelhana da redacção original da Crónica de 1344, na porção em que a refundição circa 1400 a havia mais profundamente desfigurado ${ }^{11}$. Porém, por essa altura, a colagem da personalidade literária do Conde de Barcelos ao texto editado por Cintra estava já feita, e, na prática, irá prevalecer na opinião culta portuguesa ${ }^{12}$. Quanto à porção da tradução castelhana da redacção original em que a refundição não introduziu alteraçôes de fundo, permanece ainda inédita na quase totalidade, e embora alguns autores façam dela um uso

descrição actualizada destes testemunhos, ver Catalán (1970: LXXIII-LXXIV).

${ }^{5}$ Ed. Cintra (1954, 1961 e 1990).

${ }^{6}$ Ver Cintra (1951: XXIX-XL).

7 Esta porção da Crónica de 1344 é chamada «nẫo-cronística» por a sua atípica estrutura ser alheia ao modelo historiográfico alfonsino. Cintra (1951: XXXI-XXXVI) e Catalán (1970: XVI-XVII, XXX e LII) descrevem o seu conteúdo e destacam a importância que os esquemas genealógicos, aplicados à história universal ou local, apresentam em várias das suas passagens. Contudo, essa matriz alternativa, embora marque fortemente o texto, não é suficiente para, por si só, dar conta das perplexificantes repetiçōes de matéria, recuos temporais e reajustamentos espaciais que nele se verificam. Ferreira (2010) esboça uma nova proposta de entendimento dos princípios estruturantes que presidem à selecção e ordenação da matéria historiográfica na secção inicial da crónica tal como o Conde de Barcelos a idealizou.

${ }^{8}$ Ver Cintra (1951: XXXVI-XXXVIII).

${ }^{9}$ Ver, a esse respeito, as observaçōes de Inés Fernández-Ordóñez (2008) sobre os processos de reescrita historiográfica medieval.

${ }^{10}$ Esta porção da crónica teve como fontes principais um testemunho da versão amplificada da Estoria de Espanha, entre Ramiro I e Vermudo III, e, subsequentemente, a Crónica de Castela e uma Crónica Particular de S. Fernando. Ver Cintra (1951: CCCX-CCCXVI), Catalán (1962: 305-312 e 1970: XLIV-XLIX).

${ }^{11}$ A edição crítica de Catalán e Andrés (1970) - referida neste estudo como ed. Catalán (1970) - dá a conhecer os foll. $1 \mathrm{r}-55 \mathrm{v}$ do Ms. $M$.

${ }^{12}$ Afirmação verdadeira mesmo em âmbito universitário, onde tal identificaçấo textual tende a ser em teoria reconhecida como abusiva sem no entanto restringir na prática o uso do texto da edição Cintra como representativo da época e do meio próprios de D. Pedro Afonso. 
pontual ${ }^{13}$, encontra-se virtualmente intocada por estudos específicos ${ }^{14}$. Num tal panorama, estamos ainda longe de dispor de um texto que possa considerar-se representativo da Crónica de D. Pedro de Barcelos.

Quanto ao Livro de Linhagens, os problemas são diferentes, mas igualmente perturbadores do estabelecimento da autoria. Não oferece dúvida a atribuição ao Conde de uma redacção desta obra datável de entre 1340 e $1344^{15}$. Porém, este nobiliário, tal como nos chegou ${ }^{16}$, foi sujeito ao longo do século XIV não apenas a sucessivos acrescentos $^{17}$, mas a complexas reformulações, tratadas por António José Saraiva e José Mattoso $^{18}$, das quais se destaca a que terá sido levada a cabo circa 1380 , centrada na linha de descendência Maia/Trastâmara/Pereira, que ocupa o título XXI da obra ${ }^{19}$. Contudo, os limites textuais e ideológicos desta intervenção mantêm-se difusos, e daí advém que muitos dos episódios narrativos mais extensos do nobiliário se encontrem sob suspeita de refundição ${ }^{20}$. Está, pois, minada a credibilidade da chancela do Conde de Barcelos sobre muitos dos interessantíssimos relatos romanescos presentes no Livro de Linhagens que a tradição lhe atribui.

Assim sendo, o Conde de Barcelos tornou-se uma espécie de pai putativo de um conjunto de obras que parecem de facto ter surgido por sua iniciativa mas que, no decorrer do tempo, se terão afastado da redacção inicial, convertendo-se numa amálgama textual refractária a tentativas de interpretação enquanto escrita coerente e culturalmente significativa.

\section{A unidade ideológica da obra do Conde}

O que aqui me proponho é apresentar algumas observaçóes que apontam no sentido oposto. Advogar que, quando nos debruçamos criticamente sobre os testemunhos mais ou menos adulterados que da escrita do Conde nos restam, vemos emergir uma persona-

${ }^{13}$ Ver Armistead (2000) e Dias (2003).

${ }_{14}$ Ressalvando-se alguns episódios de maior vulto transcritos e estudados no contexto de provas académicas. Ver Ferreira (2005: 689-754) e Gomes (2006: 108-117).

15 Ver Cintra (1951: CLXXXIV-CLXXXVI).

${ }^{16}$ Ver Mattoso (1980: 9-34) e Mattoso (1999: 575-580).

17 Ver Veiga (1943).

${ }_{18}$ Ver, respectivamente, Saraiva (1971) e Mattoso (1980: 7-8, 34-50, e 1999: 575-580).

19 Sobre a importância concedida no Livro de Linhagens do Conde e suas reformulaçóes a este ramo de entronque feminino na linhagem da Maia, ver Krus (1994).

${ }^{20}$ Ver Saraiva (1971) e Mattoso (1980: 43-44, e 1999: 576). 
lidade autoral bem definida, conscientemente interventiva e que, mais do que compilar fontes, as reescreve numa perspectiva orientada ${ }^{21}$. O que essa personalidade autoral nos deixou não tem nada de avulso, de casuístico ou de flutuante; pelo contrário, constitui verdadeiramente uma obra, dotada de uma coerência ideológica profunda e portadora de uma intencionalidade poderosa, apesar das contradiçóes ou paradoxos que surgem por vezes à flor do texto.

Como ponto de partida, é importante ter em mente que D. Pedro Afonso foi, antes de mais, um linhagista - como a atípica porção inicial da redacção primitiva da Crónica de 1344 não deixa esquecer. Assim, irei focar-me em duas das grandes linhagens ibéricas medievais, a castelhana Casa de Lara e a portuguesa Casa da Maia, mais precisamente na forma como as respectivas origens míticas aparecem representadas nas obras historiográficas atribuídas ao Conde de Barcelos (usarei, por um lado o Livro de Linhagens, na edição crítica de Mattoso, e, por outro a Crónica de 1344 - segundo o manuscrito $M$ da BUS ${ }^{22}$ e, como texto supletivo, a Refundição c. 1400 na edição crítica de Cintra).

O episódio fundacional da linhagem de Lara, a chamada «lenda dos Sete Infantes», encontra-se duplamente presente na obra do Conde, onde comparece no Livro de Linhagens e na Crónica de 1344. Verificam-se, quer entre essas duas ocorrências, quer relativamente às fixaçôes prévias do mesmo episódio nas sucessivas versôes da Estória de Espanha, discrepâncias curiosas que, como defendi num trabalho anterior, a análise de fontes não permite esclarecer satisfatoriamente ${ }^{23}$. Começando pelo nobiliário, a lenda dos Infantes encabeça o título X, dedicado à Casa de Lara. Nesta versão, singulariza-se não tanto pela brevidade, comparável àquela com que comparece na Crónica Abreviada de D. Juan Manuel, mas pela profunda alteraçáo de enfoque narrativo relativamente a todos os restantes testemunhos, anteriores ou posteriores, da lenda. Com rigor, seria mais adequado chamar-lhe «episódio do nascimento de Mudarra Gonçalez, patriarca da linhagem de Lara», pois é esse o acontecimento que, no Livro de Linhagens, orienta o relato. Na sombra, ficam várias personagens a quem a tradição alfonsina dava grande peso no drama da morte dos infantes (Rui Vasquez, D. Lambra, D. Sancha), já que toda a acção se centra aqui nos

${ }^{21}$ Por vezes, as manipulaçōes de informação recebida são tão flagrantes e revelam-se tão conscientes da construção de um novo sentido que bem poderíamos acrescentar Pedro de Barcelos à ilustre galeria medieval de historiógrafos «falsários» ibéricos - Lucas de Tuy, Rodrigo de Toledo, Afonso X... - apresentada por Georges Martin (2001).

22 Transcrição da porçấo correspondente (foll. 119r-143v) em Ferreira (2005: 690-753).

${ }^{23}$ Cintra tentou explicar esta e outras singularidades dos relatos do Conde como fruto de diferenças entre as fontes, algumas das quais não identificáveis, que D. Pedro teria à sua disposição nos dois momentos de escrita, o do nobiliário e o da crónica. Para uma refutação detalhada desta ideia, ver Ferreira (2005: 79-111). 
ascendentes familiares de Mudarra: o seu pai Gonçalo Gustioz, e a sua mãe, apresentada como prima do rei mouro Almançor. Outro traço distintivo desta versão é o destaque dado ao mesmo Almançor, que surge como a personalidade mais destacada do episódio, modelo de grandeza, liberalidade e equidade régias.

Pois bem, o parentesco deste rei exemplar com a moura mãe de Mudarra vai ser alterado na fixação da lenda na Crónica de 1344. Aí, o Conde retoma no essencial a estrutura narrativa da lenda a que as versóes da Estória de Espanha já nos tinham habituado, mas sem surpresa, se tivermos em conta a reconhecida parcialidade da sua Crónica a favor dos Lara $^{24}$ - substitui o sucinto relato alfonsino dos acontecimentos atinentes a Mudarra por uma extensa parte onde as peripécias conducentes ao seu nascimento misto, a sua infância entre os mouros no reino de Almançor, uma vez mais representado de forma majestosa, e, por fim, as suas aventuras e glória em terra cristã se encontram notavelmente expandidas. Quanto à mãe do herói, não é aqui uma mera prima mas a própria irmã de Almançor; e, num detalhe muito significativo, este, não tendo filhos, vai instituir Mudarra, seu sobrinho avuncular ${ }^{25}$, em herdeiro de todo o seu reino e riquezas. É de realçar o facto de, na refundição circa 1400, a elaborada descrição das entrevistas amorosas entre Gonçalo Gustioz e a moura surgir muito condensada, estando, além disso, omitidos ou alterados alguns dos elementos da caracterização valorizante de Almançor que figuram no ms. $M^{26}$.

A questão da identidade da moura dá origem ainda, nesta versão da lenda dos Infantes, a um detalhe que constitui uma das mais flagrantes incongruências internas da Crónica de 1344: a dupla concepção de Mudarra. Tal como nos textos da tradição alfonsina, a crónica portuguesa refere sucintamente como Gonçalo Gustioz concebe o herói pouco depois de ser aprisionado, em Córdova, pelo rei Almançor. Nada sugere, aí, que a moura que o rei destina para a humilde tarefa de servir o cativo cristão, e que virá a ser mãe do filho deste, seja sua parente. Porém, aparentemente esquecido desta circunstância, o redactor relata de novo, e desta vez com grande profusão de detalhes, a concepção do vingador dos Infantes, situando-a agora num momento posterior da história, depois de Gonçalo Gustioz ter tido a fatídica notícia da morte dos seus sete filhos. Ora, a moura que neste passo figura como mãe de Mudarra é a própria irmã de Almançor, enviada por este, condoído, para consolar o pai dos Infantes, destroçado pelo luto. Isto, com poucos fólios de permeio. Qualquer que possa ter sido a causa próxima deste deslize, ele denuncia a insegurança de quem compila

\footnotetext{
${ }^{24}$ Ver Cintra (1951: CXX-CXXV), Escalona (2000: 151, n.1) e Doubleday (2004: 113, 117-118, 167-170).

25 Sobre o avunculato, ver Ruiz-Doménec (1984: 227).

${ }^{26}$ Ver Ferreira (2005: 631-666, 671-673).
} 
e redige ao reunir numa mesma sequência narrativa os elementos imperfeitamente compatibilizados de um relato ainda em processo de construçáo.

Posto isto, retornemos à questão genealógica. Na longa série de fixaçôes historiográficas da matéria lendária dos Sete Infantes iniciada por Afonso X, os escritos do Conde de Barcelos serão os primeiros a mencionar a existência de uma relação de parentesco entre a mãe de Mudarra e Almançor ${ }^{27}$. Curiosamente, essa relação concretiza-se em laços diferentes nas duas fixaçóes da história de Mudarra, que, sucessivamente, D. Pedro Afonso irá patrocinar: de filho de uma prima, o herói passa a filho da irmã do rei mouro. O que terá então motivado o estreitamento do parentesco da mãe de Mudarra com Almançor, entre o nobiliário e a crónica do Conde? Estariam ambos os laços familiares consignados em fontes diferentes e anteriormente desconhecidas, que teriam chegado às mãos do Conde separadamente, sendo que aquela que referia o laço familiar mais próximo apenas lhe teria sido acessível após a interrupção do seu labor genealógico, já bem entrada a década de 1340 ? É uma hipótese possível, claro, mas uma hipótese que se revela fraca, em termos de generalidade e de economia, quer do ponto de vista meramente mecânico de filiação de relatos, quer do ponto de vista hermenêutico. Com efeito, tal hipótese apenas permite explicar um dado isolado, a alteraçáo do parentesco, quando o que aqui está em causa é um conjunto de indícios apontando para um percurso de valorização social e ética da ascendência moura de Mudarra Gonçalez ${ }^{28}$. Afinal de contas, mesmo na breve forma genealógica da lenda adoptada pelo Livro de Linhagens, Almançor era já apresentado como uma personagem de estatura superior. A longa narrativa da Crónica de 1344 mais não faz do que trabalhar textual e ideologicamente, levando-os mais longe, os mesmos elementos valorativos já convocados no nobiliário, tecendo assim imageticamente, nas entrelinhas do texto, uma reconfiguração conciliante da relação, ou de alguns tipos de relação, entre cristãos e mouros peninsulares. Um traço ideológico que temos razóes para supor ser uma idiossincrasia do Conde de Barcelos, já que, como foi dito acima, a refundição circa 1400 o irá rasurar.

Até este momento, lidámos com textos cuja paternidade podemos, de forma fiável, atribuir ao Conde de Barcelos. Mas vejamos se a sua obra putativa contém outros elementos que apontem na mesma direcção. Reveladoramente, Mudarra Gonçalez não é o único filho de moura nobre e pai cristão a quem cabe ser o patriarca de uma linhagem ilustre.

\footnotetext{
${ }^{27}$ A versão amplificada da Estória de Espanha não a afirmava, mas continha já os elementos que permitiam deduzi-la, ao referir que Mudarra era parente de Almançor, o que não poderia acontecer senão por parte da mãe.

28 Ver Ferreira (2005: 91-95, 671-673).
} 
No mesmo caso se encontra Alboazar Ramirez, de quem descendem os fidalgos da casa da Maia, segundo o muito reformulado título XXI do Livro de Linhagens ${ }^{29}$. Aí, Alboazar Ramirez é então o filho do Rei Ramiro II de Leão e da irmã do rei mouro de Gaia, Alboazar. Digo no Livro de Linhagens do Conde, porque, tal como a lenda dos Sete Infantes, também a lenda de Gaia, um complexo relato de raptos e contra-raptos de mulheres cristás por homens mouros e de mulheres mouras por homens cristãos no qual se prendem as raízes míticas da família da $\mathrm{Maia}^{30}$, tinha sido previamente objecto de fixação genealógica, neste caso no Livro Velho de Linhagens, ainda do século XIII ${ }^{31}$. Ora, nessa versão anterior, nem o rei cristão em causa é inequivocamente Ramiro II, confluindo nele elementos que podem apontar quer para o I quer para o II Ramiros da tradição historiográfica leonesa ${ }^{32}$, nem a moura de quem ele vem a ter um filho é irmã do rei mouro. Trata-se apenas de uma serviçal no palácio deste, que se torna adjuvante de Ramiro quando ele aí se apresenta para recuperar a rainha que o rei mouro, pintado com negras tintas, lhe tinha raptado.

No nobiliário do Conde, porém, não só a mãe de Alboazar Ramirez é a irmã do rei Alboazar, raptada por Ramiro II, como, contradizendo uma vez mais o Livro Velho, é sobre o rei cristão que recai o ónus do primeiro rapto. Abre-se assim espaço para uma caracterização valorizante do rei mouro, que, em contraste, surge como um modelo de qualidades, justo e magnânimo. Além disso, este relato genealógico é internamente coerente, e apresenta, por isso uma superior eficácia narrativa. Com efeito, não só nobilita a moura destinada a ser a matriarca da linhagem da Maia, como resolve satisfatoriamente o dilema da duplicação de funçốes das personagens mouras femininas, que acima vimos ser necessária para distinguir, por um lado, a mulher não guardada que serve o rei cristão em posição desfavorável em terra de mouros, e, por outro, a mulher de alta estirpe e impoluta reputação que irá gerar o filho deste.

${ }^{29}$ O tal cuja certa reformulação torna incerta a extensão da autoria do Conde nos relatos romanceados que nele figuram.

${ }^{30}$ Ver a este respeito Miranda (1988) e Ferreira (1998).

31 Sobre a datação do Livro Velho, ver Mattoso (1999: 566-571).

32 Sobre a identificação histórica com Ramiro I, ver Miranda (2008: 23), e ainda do mesmo autor «Do Rex Ranimirus...» (no prelo). Independentemente disso, o pormenor do corno que o herói toca antes da sua prevista execuçáo, sendo embora habitual nos derivados da conto oriental sobre a infidelidade da mulher do rei Salomão - ver reconstituição da matéria narrativa em Ferreira (1998: 1567-1569) -, como é o caso da lenda de Gaia, não deixa de convocar a personagem de Ramiro II, que a cronística latina recorrentemente associa ao toque deste instrumento guerreiro, e que assim aparece imageticamente inscrita na lenda a partir do momento em que esta é protagonizada por um rei Ramiro. O estrelaçamento entre os dois Ramiros estabelece-se pois precocemente neste conto genealógico. 
Como vimos, na lenda dos Sete Infantes da Crónica de 1344, a dupla funcionalidade desta personagem leva Gonçalo Gustioz a semear Córdova de bastardos... Contudo, a narrativa do Livro de Linhagens do Conde cinde em duas a personagem feminina, estabelecendo a existência distinta de uma serviçal e de uma princesa cujas actuaçóes são no texto absolutamente disjuntas. Se, aquando da sua fixaçáo cronística da lenda dos Sete Infantes, o Conde tivesse já chegado a esta possibilidade de dilucidação do problema, é de crer que optasse por uma solução equivalente ao narrar os encontros entre Gonçalo Gustioz e as sucessivas mouras que lhe saem ao caminho. Ou seja, a versão da lenda de Gaia presente no título XXI parece de facto ser posterior à versão da lenda dos Infantes da Crónica de 1344. Mas essa versão será da responsabilidade do reformulador de 1380, ou estaria já em amadurecimento na escrita do Conde de Barcelos?

As observaçôes feitas ao longo deste estudo chamam a atenção para o facto de a exaltação da Casa da Maia a que a narrativa das respectivas origens míticas procede no nobiliário não ser feita segundo um molde particular, antes relevando de uma estratégia ideológica de fundo cuja concretização textual abrange pelo menos uma outra linhagem, a de Lara, e que pode ser notada em pontos da obra de D. Pedro Afonso que não sofreram a interferência dos mesmos refundidores. Assim sendo, afigura-se lógico entender as sucessivas versões destas lendas genealógicas como estando inscritas num mesmo continuum de coesa elaboração simbólico-narrativa. Ora, se as narrativas tiverem evoluído de acordo com um processo fortemente idiossincrático iniciado pelo Conde, a probabilidade de que, décadas depois, aqueles que refundiram a sua obra tenham retomado e prosseguido todas as especificidades significativas do processo inicial afigura-se diminuta. De facto, conforme afirmámos acima, no caso concreto da Crónica de 1344 temos indícios de que foi exactamente o contrário o apagamento dos traços significativos específicos da redacção do Conde - que veio a acontecer circa 1400. Uma reflexão que torna pertinente questionar e repensar o conteúdo e os limites da refundição circa 1380 do Livro de Linhagens.

As respostas, neste âmbito, não são nunca certezas mas hipóteses mais ou menos prováveis, conjecturas mais ou menos credíveis. Ora, dados todos os paralelismos e correspondências, quer no nível dos processos de construção simbólico-narrativa, quer no plano do alcance ideológico, detectados entre estas duas reescritas de lendas genealógicas, náo faz sentido pensá-las como tendo-se operado independentemente uma da outra. Pelo contrário, é intuitivo, e revela-se heurístico, entendê-las como etapas no desenrolar de um mesmo projecto de escrita, três tempos de concretização de um mesmo modelo conceptual em busca de expressão textual eficaz. 
Uma vez mais, é o próprio Conde, ou melhor, o que resta da sua escrita, que nos empresta elementos em favor desta argumentação. Com efeito, se dúvidas poderíamos ter acerca da ligação postulada, e entretecida, por D. Pedro de Barcelos entre estas duas ocorrências de unióes mistas de cristáo e moura - e, por intermédio delas, entre as linhagens da Maia e de Lara -, o título X do Livro de Linhagens, sobre o qual não pesa suspeita de reformulação, vem dissipá-las. Logo no início, encabeçando o relato fundacional do qual nasce Mudarra Gonçalez, lê-se: «Dom Gonçalo Gostiiz foi filho de dom Gosteuz Gonçalvez e de dona Hurtiga Ramirez, filha d'el Rei Ramiro» ${ }^{33}$. Ora esta personagem, desconhecida do Livro Velho de Linhagens, é precisamente a irmã que, com o nome de Artiga, o título XXI dá a Alboazar Ramirez: a filha de Ramiro II e da princesa moura irmã do nobre rei Alboazar $^{34}$. O que torna Mudarra Gonçalez sobrinho-bisneto avuncular, se assim se pode dizer, de Alboazar Ramirez. E, sendo a versão genealógica do nascimento de Mudarra a primeira etapa, do ponto de vista redaccional, deste elaborado entrançado de imagens e linhagens em torno das unióes mistas, esta pequena referência antecipatória revela que todo o plano genealógico estava gizado desde o início, mesmo que os pormenores da sua concretização narrativa pudessem ainda ser obscuros ${ }^{35}$.

Mais: o episódio primordial, em termos cronológicos agora, desta apropriação de bom sangue mouro por linhagens cristãs não surge num ponto aleatório do tempo peninsular mas num momento fundacional que vinha já sendo preparado desde o título III. Aí, o Livro de Linhagens afasta-se momentaneamente da sua fonte para esse passo, o Liber Regum ${ }^{36}$, alterando a inserção temporal e a situação desencadeadora da instituição dos Juízes de Castela. Com efeito, no Liber Regum, esse episódio de transferência de soberania da realeza para entidades eleitas sobrevinha na sequência da morte sem descendência de Afonso o Casto; ora, no Livro de Linhagens, a eleição dos Juízes surge isolada das fontes conhecidas, sendo transposta vários reinados, transformando-se em castigo pelos crimes de Ordonho

\footnotetext{
33 Ver ed. Mattoso (1980: 147, 10A1).

${ }^{34}$ Ver ed. Mattoso (1980: 211, 21A1). Corroborando a atribuição do laço entre as linhagens de Lara e da Maia à pena do Conde e não do refundidor, verifica-se que, na primeira redacção da Crónica de 1344, no contexto da explicação da razáo para o facto de os sete filhos de Gonçalo Gustioz serem chamados Infantes, é dito que «los del solar de Lara [...] venian de los rreyes de Leon», ed. Catalán (1970: 205, cap. 128). Ora tal afirmação encontra a sua concretização genealógica precisamente em Artiga Ramirez, personagem específica do Livro de Linhagens, que este, isolado das fontes, dá como filha a Ramiro II de Leão e como mãe a Gonçalo Gustioz de Lara.

35 Sobre as uniôes mistas e a aura messiânica de alguma forma atribuída aos heróis delas nascidos no contexto da restauração do domínio cristão sobre a terra de Espanha, ver Ferreira (2009: 192-198).

${ }^{36}$ Recuando na certeza (1962: 402) acerca do uso exclusivo do Libro de las Generaciones, enquanto representante da tradiçáo narrativa do Liber Regum, na feitura do Livro de Linhagens, Catalán (1970: LX) manifesta as suas perplexidades sobre a qual ou quais das versóes o Conde aí teria recorrido.
} 
III, filho e sucessor de Ramiro II $^{37}$. A narrativa do título XXI vem corroborar esta nova motivaçáo emprestada ao episódio, reforçando ainda a culpa de Ordonho ao associar ao "pecado [...] contra sa madre» o facto de este ter sido «deserdado dos poboos de Castela» ${ }^{38}$. Num processo de anulação simbólica imageticamente correspondente à morte sem descendência dos sete Infantes de Lara, Ordonho vê-se assim desapossado das várias vertentes do seu futuro: da soberania plena sobre Castela, reclamada pelos Juízes e sua descendência; e também do papel de patriarca da mais alta nobreza peninsular, assumido por seu irmão Alboazar Ramirez.

O reinado de Ramiro II configura-se pois, no Livro de Linhagens do Conde, como um momento nevrálgico onde simultaneamente se recusa e se renova o sangue Godo do passado. Uma encruzilhada na qual se redefine o devir da Espanha com base numa reapreciação genealógica da legitimidade que assiste àqueles que reclamam o direito de a senhorear. Porém, a renovação resultante deste processo não é unívoca, e o carisma distribui-se por vários pólos. A um desses pólos, o dos Juízes, irão buscar legitimidade as dinastias dos territórios periféricos ao poder leonês matricial, Castela e Navarra. No outro, ir-se-ão filiar, remoçados de sangue mouro, aqueles a quem o título XXI designa como os «boons e nobres fidalgos de Castela e Portugal $»^{39}$. O efectivo domínio muçulmano de parcelas consideráveis de território peninsular tinha sido definidor do modo de vida e de legitimação social da nobreza peninsular: a reconquista territorial, entendida como a obrigação e o privilégio de recuperação armada da terra que constituía património ancestral da cristandade ibérica, ou, melhor dizendo, daquelas classes guerreiras a quem a posse e a

\footnotetext{
${ }^{37}$ Ver ed. Mattoso (1980: 106, 3E19): «E os Castelâos veendo em como el rei dom Hordonho de Leon havia mortos os senhores [...] ajuntarom-se [...] e fezerom dous alcaides».

38 Ver ed. Mattoso (1980: 210, 21A1), onde é a sentença do (ainda) infante Ordonho que condena à morte a sua mãe adúltera, e é essa culpa antiga que vai mais tarde ser entendida, ("disserom despois as gentes»), como a causa profunda da perda do direito do rei Ordonho à terra de Castela. Que a questão dos Juízes de Castela terá sido objecto privilegiado da atenção do Conde, e que as manipulaçôes a que este submeteu o episódio correspondente não terão sido alheias a consideraçóes sobre as linhagens que aqui destaco, da Maia e de Lara, é sugerido também na porção inicial da Crónica de 1344. Aí, o episódio, desinserido da estrutura cronológica e dissociado de qualquer motivação explícita, é sumariamente referido no capítulo dedicado aos reis das Astúrias e Leão, ed. Catalán (1970: 205, cap. 128). Como que suspenso no tempo, encontra-se no final da relação de reis e é imediatamente seguido de uma referência elogiosa à casa de Lara, à sua alta ascendência goda e à sua filiação na linhagem real leonesa. Para uma apreciação detalhada da forma como o episódio dos Juízes de Castela é reelaborado na obra do Conde de Barcelos, ver Ferreira (2010).

${ }^{39}$ Ed. Mattoso (1980: 204, 21). Não deixa de ser curioso notar que, segundo o Conde, o filho de Alboazar Ramirez irá casar com uma neta de Nuno Rasoira, Eomeldola Gonçalvez - ed. Mattoso (1980: 212, 21A3) -, revivificando assim o alto sangue dos reis de Leão, prévio ainda à desqualificante falta de Ordonho, com o sangue novo de um dos eleitos Juízes, e colocando por conseguinte a linhagem da Maia sob um duplo carisma que de alguma forma recompóe a legitimidade dispersa.
} 
defesa da terra incumbia ${ }^{40}$. Um modo de vida velho mais do que de geraçóes, de séculos, que implicitamente instituía a guerra em forma possível de coexistência etno-religiosa de cristãos e mouros em solo peninsular ${ }^{41}$. Porém, numa Ibéria em rápida mutação política e onde a presença muçulmana, quase residual, era sentida cada vez menos como uma ameaça à soberania dos reinos cristáos e mais como uma afronta puramente religiosa, a reconquista, enquanto prática inclusiva de restauração territorial, via sobrepor-se-lhe de forma decisiva o ideal de cruzada com o seu corolário de exclusóes ${ }^{42}$. Os «boons e nobres fidalgos de Castela e Portugal» eram assim despojados da sua função simbólica de guardiães da terra, tornada obsoleta pelo inexorável curso da História.

A escrita do Conde parece começar a tomar forma por volta de 1340 . Ora a década de quarenta do século XIV e a sua fértil produção literária têm como pano de fundo um acontecimento de poderoso significado cultural e político em âmbito peninsular: a batalha do Salado. Este confronto, travado a 30 de Outubro de 1340 nas margens do rio do mesmo nome, junto a Tarifa, na ponta norte do estreito de Gibraltar, foi o culminar de um conjunto de ofensivas e contra-ofensivas bélicas centradas no domínio das águas que o estreito guardava e que, desde há décadas, a norte-africana dinastia Marinida disputava à marinha de Aragão e Castela ${ }^{43}$. Na verdade, uma questão de controlo marítimo mais do que de ocupação territorial, e que portanto se revestia de diminuta importância

40 Tanto o termo como o conceito de «reconquista» são complexos e polémicos. No contexto deste estudo, importa ter em conta que a recuperação militar da Espanha se tornou uma empresa a longo prazo cujo protagonismo foi reclamado não só pelas monarquias como pela aristocracia que as servia ou delas se servia. Para alguns aspectos relevantes da forma como as instâncias guerreiras cristás peninsulares, realeza e nobreza, se foram ao longo dos séculos de ocupação muçulmana relacionando simbolicamente com esta "reconquista", ver Ferreira (2009: 182-192).

${ }^{41}$ D. Juan Manuel, o mais destacado representante da ideologia aristocrática na Castela da primeira metade do séc. XIV, apresenta no seu Libro de los Estados um extenso, detalhado e rigoroso código de conduta guerreira destinado a ser observado pelos nobres cavaleiros cristãos na luta contra os mouros - ed. Alvar e Finci (2007: 575-587, I, lxxv-lxxix). Trata-se de preceitos muito críticos da crueldade gratuita e da pilhagem indiscriminada, aplicáveis a esta guerra específica que o nobre castelhano considera distinta de qualquer outra e a que atribui motivaçóes puramente territoriais: «á guerra entre los cristianos et los moros, et abrá fasta que ayan cobrado los cristianos las tierras que los moros les tienen forçadas; ca, cuanto por la ley nin por la seta que ellos tienen, non avrían guerra entre ellos» - ed. Alvar e Finci (2007: 429, I, xxx).

${ }^{42}$ Centrando-se em Portugal mas desenvolvendo uma argumentação extensível ao contexto peninsular, Erdmann (1940: 5) é taxativo quanto à impossibilidade de assimilar, em termos motivacionais, a reconquista peninsular, que considera uma empresa política de recuperação territorial, à noção de Cruzada, entendida como guerra santa apoiada num pressuposto de exclusividade religiosa. Os conceitos em causa são complexos e multifacetados, tornando-se difícil defini-los de forma a enquadrarem consistentemente a prática guerreira cristá contra os mouros nas diferentes realidades sociológicas e político-religiosos que se sucederam na Península ao longo dos muitos séculos de domínio muçulmano sobre parcelas maiores ou menores do território. Como abordagens recentes da problemática ideológica em torno destes dois conceitos na Ibéria Medieval, ver O’Callaghan (2003: 1-22) e a síntese de González-Jiménez (2003).

43 Sobre as circunstâncias e consequências militares e políticas da batalha do Salado, e os alinhamentos de forças que aí se perfilam de ambos os lados, ver Bishko (1975: 436-438) e Sousa (2005: 210-219). 
simbólica no contexto da representação da Espanha como património a recuperar e preservar. Contudo, o desembarque Marinida no sul com vista à captura do porto de Tarifa foi envolvido numa retórica defensiva que o assimilava a uma nova invasão moura da Espanha $^{44}$ e fazia perigar o bastiāo ocidental da cristandade. Na exaltada dinâmica assim criada, o rechaço das pretensóes dos Marinidas, entretanto aliados ao rei de Granada, congregou forças militares não apenas de Castela, o único reino peninsular que mantinha fronteira com os mouros, mas também de Aragão e Portugal contra um inimigo considerado comum.

Se para alguns sectores da sociedade peninsular, e em particular portuguesa, esta chamada às armas pôs em marcha o espírito de cruzada ${ }^{45}$, ela foi para outros vivida e entendida como a actualização e a cristalização da memória idealizada de uma Espanha a que o desígnio comum da reconquista conferia uma unidade supra-territorial. O conhecido relato da Batalha do Salado, preservado no título XXI do Livro de Linhagens do Conde ${ }^{46}$, dá testemunho da segunda destas perspectivas e constitui uma inflexível afirmação da superioridade de um modo de fazer e de viver a guerra com o mouro que encontrava nas praias de Gibraltar o seu ocaso ${ }^{47}$.

${ }^{44}$ A representação de períodos de revés contra os mouros e de crise ou ruptura política entre os reinos cristấos de acordo com um esquema que retomava basicamente, com novas personagens, a narrativa apocalíptico-providencialista da perda e da recuperação da Espanha, reencenando assim ciclicamente, com personagens adaptadas às novas circunstâncias, um passado de queda e prometida redençấo, era um recurso simbólico-narrativo a que a historiografia hispânica estava afeita. Sem contar com a efabulação sobre a culpa do Rei Rodrigo e do advento de Pelágio enquadrando a perda inicial da terra - ver Pardo (2006) -, podemos citar como exemplos de acontecimentos suscitando a utilização desta estratégia as devastaçóes de Almançor ver Bautista (2006: 72-76), que faz radicar na homologia com a perda de Espanha a construção da figura do conde Sancho Garcia de Castela segundo a Chronica Najerensis -, e a invasão Almorávida - ver Ferreira (2009: 196-198), que interpreta a reescrita da morte do infante Sancho, filho de Afonso VI e da moura Zaida, na historiografia do séc. XIII como uma alegoria da perda da Espanha.

45 Torna-se neste contexto muito relevante a observação de Bishko (1975: 438), que defende ter sido já após o fechamento da fronteira territorial com os mouros, no séc. XIII tardio e no séc. XIV, que Portugal, por intermédio das ordens militares, demonstrou maior furor cruzadístico.

46 Ver ed. Mattoso (1980: 241-56, 21G15). A questão da autoria desta narrativa sobre a Batalha do Salado, que se centra na figura do Prior do Hospital D. Álvaro Gonçalves Pereira - ver Saraiva (1971) e as observações de Amado (1993) -, está longe de estar esclarecida. A forma digna, e até elogiosa em termos de honra guerreira, como os mouros são representados, bem como a ética cavaleiresca que comanda as acçóes quer de um campo quer do outro no desenrolar da batalha, tornam-se particularmente significativas se tivermos em conta que o seu herói, sendo o mais alto dignitário de uma ordem militar, deveria estar conotado com os valores e os métodos próprios da Cruzada, que assentavam na radicalização da alteridade do mouro e na des-humanizaçáo da sua imagem e pessoa. Mesmo que possa náo ser da responsabilidade autoral directa do Conde de Barcelos, a narrativa comunga da ideologia aristocrática integradora da memória hispânica que este estudo tem vindo a explicitar na obra deste filho de D. Dinis, estando fora de dúvidas que se enquadra num projecto de escrita compatível com o que ele, em várias frentes, desenvolveu.

${ }^{47}$ O relato da Batalha do Salado incluído no Livro de Linhagens não é o único testemunho literário desta funda divergência. As repercussóes político-ideológicas da batalha e a polémica entre cristãos que, na década de 1340, opunha a reconquista à cruzada, e a defesa patrimonial e recuperação territorial à intolerância religiosa e ex- 
O Salado transformou-se no maior recontro armado entre cristãos e muçulmanos desde as Navas de Tolosa, e saldou-se por uma vitória igualmente gloriosa; mas foi também o último empreendimento conjunto da cristandade hispânica unida contra um adversário real, sem dúvida, mas com o qual a luta se tinha, ao longo dos séculos, ritualizado, tornando-se, assim, num factor poderosamente estruturante do imaginário da nobreza peninsular.

É neste contexto que pode ganhar sentido a miragem da legitimação simbólica dos valores aristocráticos em perda, associando certas linhagens ao preenchimento de expectativas providenciais através da recuperação de heróis de tipo messiânico, gerados por um pai cristão e uma mãe moura, heróis cujo destino simbólico parece ser o de trazer a ordem, a unidade e a regeneração a uma Espanha representada como dividida e destroçada a partir do seu interior ${ }^{48}$.

\section{O Conde e a ideologia neogótica}

A questão do neogoticismo, ou seja da fundamentação do direito ao senhorio sobre a Espanha na existência de uma continuidade sucessória entre a monarquia Goda e dos reinos peninsulares medievos ${ }^{49}$, é um outro aspecto que, pelas suas amplas implicaçôes na construção do pensamento político peninsular ao longo da Idade Média e mesmo já em plena Idade Moderna ${ }^{50}$, merece ser perscrutado na escrita do Conde. De facto, esse é um elemento ideológico que se revela estruturante nas mais antigas crónicas asturianas e que, afirmado, negado ou reformulado, mantém a sua actualidade na elaboração historiográfica dos reinos cristãos que, nos séculos XII e XIII se expandiam e definiam no território peninsular ${ }^{51}$. Seria

termínio étnico deixaram abundante rasto na literatura peninsular coeva. Na sua esmagadora maioria, contudo, os textos situam-se na perspectiva oposta ao relato do Livro de Linhagens. Basta lembrar o Poema de Alfonso XI, o fragmento do Poema da Batalha do Salado de Afonso Geraldes ou o muito interessante, embora menos conhecido, In sancta et admirabili Victoria Christianorum - ed. Ramos (1996) -, texto português comemorativo dessa batalha, provavelmente associado às celebrações fúnebres do rei Afonso IV, no qual a hostilidade face ao mouro, visto não como um adversário guerreiro mas como o inimigo absoluto que é imperioso erradicar, se expande para além do campo de batalha e se manifesta em actos de crueldade que náo poupam mulheres nem crianças.

48 Ver Ferreira (2009: 192-198).

49 Sobre a génese da doutrina neogótica e suas implicaçôes políticas, ver Martin (1984). Ver igualmente a síntese de Ladero Quesada (1993) e o estudo de Deswarte (2003).

50 Sobre a forma como, nos finais da Idade Média e dealbar da Idade Moderna, a posteridade literária do mito godo foi interpretada nas suas consequências jurídicas e políticas para a soberania do reino de Portugal, ver o interessante estudo de Tarrío (2006).

${ }^{51}$ Sobre o percurso do neogoticismo na Estoria de España alfonsina e suas sequelas, ver Fernández-Ordoñez (2000); sobre o neogoticismo na Chronica Najarensis e no Liber Regum, ver os recentes trabalhos de Le Morvan (2009 e 2010). 
impensável que D. Pedro Afonso se mantivesse alheio a essa ubíqua problemática legitimatória, e que a sua representação do passado ibérico não manifestasse a sua posição ideológica. Contudo, os elementos que tanto a Crónica de 1344 como o Livro de Linhagens nos fornecem sobre o assunto afiguram-se, numa primeira análise, contraditórios.

Esboçarei uma breve perspectiva crítica da questáo, que permita entender a complexidade e especificidade da posição ideológica do Conde de Barcelos. Numa síntese esquemática, é possível dizer que a evocação do domínio ancestral da terra, por um lado, e do senhorio por direito de conquista, por outro, tendem, enquanto formas de legitimação do poder sobre o território peninsular, a hierarquizar-se de forma diferenciada consoante as circunstâncias políticas. Desde pelo menos os tempos de Afonso III de Oviedo, tanto a legitimidade do título régio ostentado pela dinastia astur-leonesa, quanto a reclamação do direito ao imperium sobre a Espanha a ele associada se alicerçavam fundamentalmente no pressuposto, habilmente forjado pela historiografia coeva, da continuidade genealógica entre os reis godos da península e os reis astur-leoneses que se tinham empenhado na recuperação do território dominado pelos seus postulados avós ${ }^{52}$.

À medida, porém, que o território reconquistado aumentava e a linha de fronteira se tornava mais extensa e mais afastada do centro do poder (que, sintomaticamente, se deslocara entretanto de Oviedo para León), os poderes locais sediados nos territórios periféricos implicados não apenas na acção militar de extensão territorial e de defesa das fronteiras mas também na efectiva ocupação dos novos espaços cristãos começaram a desafiar o domínio soberano da monarquia central e a reivindicar e construir a sua autonomia política. É o caso de Navarra e de Castela; será, posteriormente, o caso de Portugal. Tal como fizera, séculos antes, a monarquia leonesa ${ }^{53}$, também estes novos poderes vão procurar na representação do passado a legitimação simbólica da sua soberania, mas desta feita para alicerçar ideologicamente a sua recusa do imperium leonês. Neste processo, o caso castelhano singulariza-se por um desvio e apropriação da legitimidade gótica, como, na segunda metade do século XII, demonstra a Chronica Najarensis ao construir um neogo-

\footnotetext{
52 Sendo controversa a ascendência goda de Pelágio, a figura de Afonso I, filho do mítico duque Pedro de Cantábria, suposto descendente de Leovigildo e Recaredo, tinha sido investida como ponto de entronque dinástico asturiano privilegiado com a linhagem dos reis godos no seu momento mais glorioso. Sobre o investimento legitimatório astur-leonês na personagem de Afonso I, ver o estudo de Escalona (2004).

53 Ver Martin (1984: 217-233).
} 
ticismo entendido não em termos étnicos e genealógicos, de transmissão do sangue real, mas éticos e ideológicos, de continuidade e defesa do conceito imperial da Espanha ${ }^{54}$.

Porém, a reformulação neogótica castelhana - a que a crescente centralidade geo-política do reino de Castela na Península Ibérica haveria de conceder longa fortuna -, constituiu a base legitimatória de pretensóes imperiais, mais do que de uma afirmação de autonomia territorial e soberania política. Aí, a representação castelhana do passado, tal como a navarra e a portuguesa, lança mão do direito de conquista e, subsidiariamente, de povoamento 55 . É neste contexto de múltiplas legitimaçôes que surge a lenda e a problemática referentes aos Juízes de Castela ${ }^{56}$, instâncias de poder instituídas numa situação de quebra de varonia ou de carisma régio, legitimadas não por sucessão genealógica mas por designação electiva pelos seus pares, e confirmadas pela sua acção em prol da conquista, defesa e povoamento da terra. O Liber Regum, datado dos finais do séc. XII, e as suas sucessivas reescritas ${ }^{57}$, caracterizadas em bloco pela interrupção da linhagem régia asturiana em Afonso II o Casto e pelo consequente advento de poderes autónomos nas regióes marginais da Navarra e de Castela, é uma das mais acabadas manifestaçóes da aspiração legitimatória de campos políticos hostis à herança leonesa do imperium visigodo, reclamando contra ela o direito de conquista. A favorável fortuna que o Liber Regum e as suas reescritas tiveram no também autonomista e periférico território de Portugal ${ }^{58}$ é significativa e indiciadora da existência de um padrão ideológico comum às margens territoriais. O movimento de oposição global que assim se esboça entre a centrípeta fixidez goticista e o dinamismo centrífugo desenvolvido pela conquista parece espelhar a tensão inevitável entre a centralidade e a periferia dos territórios em causa.

Por outro lado, como mostrou Inés Fernández-Ordoñez ${ }^{59}$, no florescimento historiográfico castelhano em vulgar das últimas décadas do século XIII, quando as coroas de Leão e de Castela se encontravam já definitivamente unidas sob a égide desta última, trans-

\footnotetext{
54 Sobre as especificidades da apropriação historiográfica do goticismo por Castela, ver Bautista (2006: 73-75 e n. 36) e Le Morvan (2009: \$\$34-39).

55 Sobre as várias acepçôes (política, administrativa e demográfica) deste conceito no âmbito da reconquista peninsular, ver Menéndez Pidal (1960). No presente trabalho, o termo é usado com o sentido - que sobressai da interpretação de Mattoso (1993: 451-457) do uso do verbo "populare» na historiografia e diplomática coevas - de imposição efectiva de um poder político sobre um território mediante a sua reorganizaçáo administrativa.

56 Sobre a evolução historiográfica deste tema fundador da autonomia castelhana e a compreensão dos valores políticos que lhe foram sendo contextualmente atribuídos, ver o magnífico estudo de Martin (1992).

57 Sobre o significado e a fortuna desta obra genealógica navarra, ver o volume 9 (2010) da revista on-line e-Spania, que lhe está inteiramente dedicado.

${ }^{58}$ Ver Cintra (1950a, 1950b, 1951: XCVII-CV), Catalán (1962: 305-312, 357-408, e 1970: LIII-LXII, Miranda (2009a: 72, 90-91, e 2010) e Ferreira (2010).

59 Ver Fernández-Ordońez (2000).
} 
formando assim aquilo que tinha sido um território periférico e autonomista no centro político da Espanha reconquistada de «mar a mar» ${ }^{60}$, a questão neogótica mantinha-se actual. Mais do que no direito à recuperação da terra e ao seu senhoreamento efectivo, centrava-se contudo, agora, na aspiração ao imperium sobre a Espanha, por parte de Afonso X, e na legitimidade e consequências da divisão dos reinos cristãos peninsulares no âmbito da reconquista ${ }^{61}$. De facto, tanto a redacção primitiva da Estoria de España como a Versão Crítica da mesma obra, ambas elaboradas sob a chancela alfonsina, reclamam a continuidade entre a dinastia castelhano-leonesa e a monarquia goda e repudiam a ideia da divisibilidade do imperium sobre a terra cristã. Nenhuma destas situaçóes encontra eco na Versão Amplificada de 1289, elaborada no reinado de Sancho IV, obra que se manifesta, pelo contrário, favorável à ideia de que a recuperação territorial cabe aos «naturais» da terra, não sendo um direito exclusivo dos eventuais herdeiros dos reis godos ${ }^{62}$. Pouco depois, a Crónica de Castela irá veicular propósitos semelhantes.

Estes diferentes posicionamentos ideológicos correlacionam-se, por um lado, com a afirmação regalista constitutiva dos escritos alfonsinos, onde se verifica uma crescente preocupação com o reforço das prerrogativas e autoridade do monarca, e, por outro, com a representação estamental da Espanha presente na Versão Amplificada e na Crónica de Castela, onde o governo resulta de um pacto entre o monarca e a aristocracia que o apoia e coadjuva, de tal forma que o rei não é já o único agente da história, dividindo o protagonismo com os «altos homens» do reino.

Ora, pelos mesmos anos de 70 e 80 em que Afonso X de Leão e Castela invocava a legitimidade goda como fundamento do imperium, o goticismo parece não ter tido expressão favorável no reino de Portugal. Os textos de natureza historiográfica em vernáculo do ocidente peninsular contemporâneos dos escritos alfonsinos ou anteriores a eles o Livro Velho de Linhagens, de circa $1270^{63}$, e a Primeira Crónica Portuguesa, anterior a $1282^{64}$ - são sem margem para dúvida redigidos na perspectiva legitimatória decorrente do direito de conquista. O primeiro propóe-se falar das linhagens dos «bons homens filhos

\footnotetext{
${ }^{60}$ É com esta expressão que o séc. XIII guarda a memória da acção conquistadora de Fernando III, pai de Afonso X, tanto na tradição da Estoria de España como na lírica trovadoresca.

${ }^{61}$ Ver Fernández-Ordoñez (2000: 43-49, 55-58).

62 Ver Fernández-Ordońez (2000: 61-62, 65).

63 Ver Mattoso (1999: 566-571). Alguns detalhes formulares e linguísticos do Livro Velho de Linhagens levaram Miranda (2009b) a pôr a hipótese de que a mais antiga obra genealógica portuguesa terá conhecido o Liber Regum, com cuja ideologia anti-centralista parece em vários pontos identificar-se.

${ }^{64}$ Ver Moreira (2008: 67-80).
} 
d'algo [...] que andaram a la guerra a filhar o reino de Portugal» ${ }^{65}$; o segundo apresenta o reino de Portugal como um território ganho pelas armas do seu primeiro rei e autonomizado pela oposição armada às lealdades galegas da nobreza portucalense e ao imperialismo leonês. Dois textos redigidos no quadro do diferendo entre a nobreza e a coroa que marcou o reinado de Afonso III de Portugal após meados da década de sessenta do século XIII ${ }^{66}$, porém procedendo de meios diversos e com objectivos opostos, sendo um deles guiado pela afirmação da nobreza e o outro pela exaltação da realeza de Portugal. Dois textos que, apesar dessas divergências e contrariamente ao que se passava em Castela, comungam do mesmo alheamento face à legitimidade neogótica, aderindo em bloco ao direito de conquista. Os argumentos legitimatórios parecem assim ordenar-se, no decurso do século XIII, segundo um duplo paradigma que opóe em eixos que se articulam entre si, aristocracia contra monarquia e autonomia periférica contra a centralidade do poder territorial.

Neste pano de fundo, a invocação pelo Conde, na década de quarenta do século seguinte, da ascendência goda dos Lara, e as complicadas manobras de entronque das casas de Lara e da Maia na monarquia astur-leonesa, que acima foram tratadas, parecem destacar-se como manifestaçóes de um passadismo mal interpretado, desenquadrado de ambos os eixos paradigmáticos acima referidos e no qual a ascendência goda dissociada de qualquer reclamação de dignidade régia surge como um traço desfuncionalizado. Semelhantemente, o objectivo expresso do Conde, no Livro de Linhagens, de «meter amor e amizade antre os nobres fidalgos da Espanha ${ }^{67}$, parece configurar uma recusa da oposição distintiva entre centro do poder e periferia territorial. Ora, nas obras historiográficas do século anterior, a ausência dessa oposição equivalia, em termos ideológicos, à assunção da invisibilidade política dos territórios marginais e à apologia de uma soberania única. Posição sobremaneira estranha, tendo em conta por um lado que quem fala é filho do rei de um território periférico, Portugal, e, por outro, que náo se perfila no horizonte do discurso por ele enunciado nenhuma figura régia que possa ser o recipiente de um poder peninsular único e soberano. Pelo contrário, é invocada a autoridade axiomática da máxima sabedoria antiga para postular a dispensabilidade de um monarca: «Esto diz Aristotles: que se homées

${ }^{65}$ Ed. Piel e Mattoso (1980: 23).

${ }^{66}$ Sobre o contexto politico de afirmação régia e "domesticação" da nobreza tradicional onde este diferendo se origina, ver Mattoso (2009: 532-542).

${ }^{67}$ Ed. Mattoso (1980: 55). 
houvessem antre si amizade verdadeira nom haveriam mester reis nem justiças ca amizade os faria viver seguramente em no serviço de Deus» ${ }^{68}$.

A adensar este quebra-cabeças, temos os elementos que apontam para uma aceitação sem reservas da descontinuidade entre a monarquia goda e a monarquia asturiana. Nesse sentido, funcionam as referências, sucessivamente reiteradas ao longo das complicadas circunvoluções de escrita características da porção inicial da Crónica de 1344, que não deixam esquecer que o fim da monarquia goda se dá com o rei Rodrigo, «el que perdio la tierra» e foi o "postrimero rrei de los godos» ${ }^{69}$. Tais referências surgem mesmo em pontos em que o Conde não se limita a seguir as fontes mas redige capítulos de síntese originais, realçando por conta própria essa situação de fecho de um mundo ${ }^{70}$. Também a ascensão de Pelágio ao trono asturiano é, na mesma obra, sucessivamente apresentada em redacçóes ligeiramente distintas mas de sentido concordante ${ }^{71}$. Embora não seja nunca explicitamente negada a ligação do primeiro chefe guerreiro da reconquista ao mundo godo que ruía, o texto não fornece quaisquer elementos que possam indiciá-la positivamente. Pelo contrário, a ascensão de Pelágio à dignidade régia é consistentemente relatada como uma eleição motivada por consideraçóes estritamente guerreiras e territoriais: «E los christianos que sse acogeron a las montanañas de Asturias quando fu el desbarato del rrei don Rrodrigo, veyendo que se perdia la tierra, alçaron por rrei entre si el rrei don Pelayo, el que llamaron Montesino». Donde se deduz, por um lado, que Pelágio não é mais nem menos godo do que aqueles «christianos» que o elegem; e, por outro, que não é para dar continuidade à dinastia goda que é eleito: «E fue alçado por rrei en las cuevas de Esturias. E deste rrei en adelante non fueron llamados godos» $»^{72}$.

Igualmente significativa é a forma como, já na parte da Crónica de 1344 que tem como fontes principais obras da tradição cronística pós-alfonsina ${ }^{73}$, o Conde acolhe o episódio da partição dos reinos de Fernando I pelos seus filhos. De acordo com a tradição alfonsina,

${ }^{68}$ Ed. Mattoso (1980: 55).

${ }^{69}$ Estas afirmaçôes são sucessivamente reiteradas. Ver ed. Catalán (1970: 27-28, 197, 199-200).

${ }^{70}$ No curiosíssimo capítulo 127 da Crónica de 1344, ed. Catalán (1970: 197-199), que faz o computo dos reis (não mouros) que foram senhores de Espanha desde o advento dos Godos até Afonso XI e recorda em traços largos as circunstâncias em que se deram entretanto mudanças de senhorio, é estabelecida uma distinção explícita entre dois grupos de reis: «Asi que los rreyes godos fueron por toda cuenta treynta e seys. E los rreyes de Leon e de Castilla fueron por toda cuenta treynta e siete» (198).

${ }^{71}$ A eleição de Pelágio surge sempre associada à perda da terra por Rodrigo - ver ed. Catalán (1970: 27-28, 197, 199-200).

72 As citaçôes deste parágrafo correspondem à versão do episódio da eleição de Pelágio e consequente translatio do senhorio da Espanha que é contada no cap. 127, ed. Catalán (1970: 197-199).

73 Trata-se da secção da redacção primitiva ainda inédita, testemunhada pelo Ms. $M$. 
Fernando Magno recusa acatar a objecção à partição dos reinos apresentada por seu filho Sancho, que alegava que a antiga lei goda não permitia a divisão da Espanha. Porém, enquanto nos textos da Estória de España esta recusa se configura como uma afirmação gratuita de poder régio "lo non deixarie de fazer por esso" ${ }^{74}$, na Crónica de 1344 Fernando invoca o direito que lhe assiste de fazer a sua vontade pelo facto de a uniáo dos reinos ser um feito seu pessoal e náo algo que lhe tivesse sido legado: «lo non deixaria de fazer por esso ca el lo gańara $»^{75}$. Este argumento, ecoando o primado do direito de conquista sobre a legitimidade goda, não é original do Conde, pois aparecia já na Crónica de Castela ${ }^{76}$, que é neste ponto a fonte principal da Crónica de 1344. Mas não deixa de ser significativa a adesão de D. Pedro Afonso ao novo ponto de vista, tanto mais que, no mesmo passo, aceita igualmente a substituição da expressão «imperio d'España», usada nas versóes da Estoria de España, por «senhorio d'Espanha», preferida pela Crónica de Castela. Com efeito, a forma «senhorio» está muito menos conotada com uma centralidade monárquica única e absoluta e revela-se neste contexto mais compatível com uma pluralidade de instâncias de poder.

O pensamento político do Conde de Barcelos parece assim eivado de contradiçóes. Não nega a ascendência goda de Pelágio, mas entende que a monarquia goda termina com a perda da terra pelos godos e que Pelágio é eleito pelos seus pares por razóes de mérito militar e não de direito linhagístico. Não dá lugar, na identificação dos membros da nobreza - «os nobres fidalgos da Espanha» -, à naturalidade definida em termos de pertença a um reino, mas nem por isso se mostra contrário à divisão dos reinos e adepto do imperium peninsular. Coloca-se numa perspectiva ideológica em que prevalece o direito de conquista, e apesar disso acentua a ascendência goda das linhagens que na sua obra favorece. Proclama a possibilidade de uma sociedade governada apenas com base nos laços de solidariedade entre os elementos da nobreza, mas empenha-se em fazer entroncar na monarquia astur-leonesa os antepassados míticos dos mais destacados representantes dessa mesma nobreza.

Talvez seja este último ponto - e mais concretamente as acima referidas manipulaçóes levadas a cabo pelo Conde, no Livro de Linhagens, em torno de Ramiro II e da instituição dos Juízes de Castela - que pode ajudar a destrinçar uma linha de sentido no meio da aparente amálgama de proposiçóes incoerentes acima enunciada. Pensemos no panorama

\footnotetext{
${ }^{74}$ Ver, para a Versión Amplificada, ed. Menéndez Pidal (1955: 494b, cap. 813) e para a Vérsión Crítica, ed. Hernández Alonso (1991: 173b, Livro Vlll, cap. 14).

75 Ms. $M$, fol. $210 \mathrm{v}$, col. 2.

${ }^{76}$ Ed. Lorenzo (1975: 348, cap. 205).
} 
historiográfico português coevo, que os estudos de F. A. Moreira e J. C. Miranda presentes neste volume caracterizam, e que constituem ao fim e ao cabo o quadro de referências histórico-literárias no qual o Conde de Barcelos tinha aprendido a movimentar-se. Como genealogista que era, a sua obra estava sobretudo marcado pela tradição do Liber Regum ${ }^{77}$. Ora a premissa ideológica estruturante dessa família de textos é que a legitimidade da dinastia régia iniciada por Pelágio sofreu um revés que redundou na instituição dos Juízes de Castela e pôs em causa o direito à soberania dos monarcas que subsequentemente se vieram a reclamar da linha astur-leonesa. Pois bem, o que o Conde faz é partir dessa premissa e procurar na dinastia régia das Astúrias e de Leão ${ }^{78}$ um momento áureo, logicamente anterior à questão dos Juízes, aonde as linhagens que quer exaltar possam ser favoravelmente enxertadas. Rejeita, evidentemente, que o advento de Nuno Rasoira e Lain Calvo tenha sido causado por quebra de varonia após o reinado de Afonso II, pois nesse caso não poderia fazer entroncar na cepa régia os patriarcas da Maia e de Lara. Em vez disso, opta por uma perda de carisma subsequente a uma grave falta de ética do monarca consubstanciada em Ordonho III, o filho de Ramiro II $^{79}$. Assim, e como se mostrou acima, ao mesmo tempo que concentra na descendência alternativa de Ramiro II todo o prestígio dos obreiros iniciais da reconquista, o Conde de Barcelos deixa a linhagem régia de Leão-Castela manchada por uma imperdoável traição à nobreza.

Por outro lado, uma vez que não nega que os reconquistadores iniciais possam ser godos, mas proclama que a legitimidade da posse da terra lhes é conferida pelos feitos guerreiros e não pela ascendência, o Conde coloca Pelágio no mesmo plano em que poderia estar qualquer heróico godo (ou não godo) que tivesse sobrevivido ao desastre em que tinham perecido a monarquia visigoda e o império cristão da Espanha e se tivesse refugiado nas Astúrias: «Quando se perdio el rrei don Rodrigo [...] en aquellas montañas

77 Sobre a fortuna do Liber Regum em Portugal anteriormente a 1340, ver Miranda (2010); sobre o uso do Liber Regum pelo Conde D. Pedro, ver Ferreira (2010). Ambos os artigos referem estudos anteriores na respectiva problemática.

${ }^{78}$ Não o esqueçamos, na sequência de Pelágio e da sua eleição guerreira, esta dinastia encabeça o prestigioso processo de reconquista e repovoamento da terra de Espanha, mas além disso, e através do entronque com Afonso I - ver Escalona (2004: 251-255) - reclama também a herança gótica imperial dos antigos monarcas.

79 Trata-se do traiçoeiro assassínio dos condes castelhanos, que o Conde irá reforçar ainda, como ficou dito acima, com a sentença de morte contra a mãe ditada por Ordonho III. A substituição da esterilidade de Afonso II, enquanto causa da eleição dos Juízes de Castela, por acontecimentos negativos decorrendo da responsabilidade activa de monarcas Leoneses não é um estratagema original do Conde, tendo sido inaugurado pelo Tudense que situava essa eleição no reinado de Fruela II, e afinado pelo Toledano, que mantém a colocação do episódio definida pelo seu antecessor mas implica ainda o comportamento iníquo do rei anterior, Ordonho II, nas causas da eleição. Sobre esta questão, ver Martin (1992: 212-229, 270-295). 
se acojeron toda la gentes de la tierra que escaparon de la batalla ${ }^{80}$. Assim, em vez de estar concentrada na dinastia régia troncal, a legitimidade suplementar que uma ascendência goda pudesse atribuir é distribuída por todos os descendentes desses sobreviventes iniciais - o que irmana toda a aristocracia guerreira no mesmo direito à conquista da terra e inviabiliza eticamente a reclamação do imperium por uma linhagem particular.

Não será afinal esta idealizada comunidade de guerreiros a razão pela qual o Livro de Linhagens, ao contar a entrada dos godos em Espanha e os caracterizar enquanto povo, refere, de acordo com o Liber Regum que «Estes Godos forom do linhagem de Goth e de Magoth e de Jafet, o filho de Noe, e forom gentiis», mas regista também, dado que a tradição textual canónica desta fonte não contempla ${ }^{81}$, «E forom todos cavaleiros» ${ }^{82}$ ? Antes de terem ganho e perdido a Espanha, os godos eram já, no dizer do Conde, uma sociedade de cavaleiros - e essa matriz ético-social configura uma forma de nobreza dotada de valor intrínseco e que, contrariamente à condição régia, perdura para além da perda da terra. A herança goda não se projecta, afinal, no protótipo de uma monarquia, mas no de uma organização estamental da Espanha. É este, segundo os textos parecem permitir entender, o neogoticismo de que o Conde de Barcelos faz a apologia: um goticismo aristocrático que sobrelegitima a nobreza guerreira da reconquista e que, acima do poder autonómico dos reinos divididos ou do centralismo de uma monarquia imperial, proclama a inteireza de uma Espanha fundada na unidade dos seus «nobres fidalgos» no propósito da recuperação da terra.

De Covadonga, entrincheirada nas montanhas do extremo norte, a Tarifa, guardando a sul as portas de África, é afinal o percurso dos restauradores da Espanha, uma Espanha instituída in illo tempore pelos cavaleiros godos, que a pena do Conde de Barcelos traça. Um percurso mítico recobrindo com uma idealização de supremacia aristocrática pan-hispânica o real significado social, político e ideológico da reocupação Cristã do território peninsular. E a batalha do Salado figura no final desse traçado como o rito que sela a pervivência do passado enquanto mito.

${ }^{80}$ Ed. Catalán (1970: 199-200)

${ }^{81}$ Este elemento não se encontra nas versôes Vilarense nem Toledana do Liber Regum, nem no seu derivado Libro de las Generaciones, encontrando-se apenas na curiosa súmula da história de Espanha desde a chegada dos Godos até Fernando Magno, largamente baseada no Liber Regum, que serve de introdução à Tradução Galego-Portuguesa da Crónica de Castela - ed. Lorenzo (1974: 900-903) - contida no ms. A2 do códice factício A, 8817 da Biblioteca Nacional de Espanha. Sobre este interessante texto, ver Miranda (2009a). Para novas perspectivas ver Bautista(2010).

${ }^{82}$ Ed. Mattoso (1980: 101, 3D1). 


\section{O Conde, a escrita e a memória}

«E pero que é ben que o ben que home faz sse non perça, mandamo-lo screver», diz a conhecida epígrafe, remontando ao Livro das Cantigas do Conde que antecede nos cancioneiros trovadorescos as composiçóes de Vidal, judeu de Elvas ${ }^{83}$. Com base no puro mérito poético, D. Pedro de Barcelos fazia assim ombrear com os protagonistas da manifestação mais emblemática da cultura aristocrática peninsular, tal como a tinha conhecido, um desclassificado elemento da sociedade. O interesse desta epígrafe, muitas vezes evocada pelo seu carácter pitoresco, não se esgota porém no testemunho de preconceituação etno-religiosa que a contrario fornece. Ela alcança, na verdade, muito além, pois contém em si todo um programa de escrita governado por uma ética de que o autor se assume como intérprete e guardião. Vidal é resgatado à invisibilidade a que a sua lei tacitamente o condena pelo superior entendimento daquele que, em nome de uma noçáo abstracta de Bem, tem o poder e o dever de identificar e de preservar esse mesmo Bem. Um Bem com ressonâncias Aristotélicas, invocado num enunciado universalizante que não se aplica apenas à poesia mas à generalidade dos feitos humanos, e que deve ser assinalado por aquele que tem sobre o tempo o poder de, pela escrita, o cristalizar em memória. Para que o Bem se não perca.

É nesta perspectiva que ganha pleno sentido a escrita do conde D. Pedro no seu afã compilatório, simultaneamente rememorativo e comemorativo, de cantigas, linhagens e histórias, reconfigurando o passado de modo a poder encerrá-lo. Não havendo já terra a guardar, restava guardar a memória.

83 Trata-se de duas cantigas truncadas que comparecem em ambos os cancioneiros quinhentistas, com os números 1605 e 1606 no Cancioneiro da Biblioteca Nacional e 1138 e 1139 no Cancioneiro da Vaticana. A transcrição da epígrafe segue a ediçâo de Luciana Stegagno Picchio (1979: 85). Na sequência de Carolina Michaëlis, esta autora considera tratar-se de uma epígrafe emanando da vontade directa do mandatário da compilação onde as composiçôes de Vidal foram integradas, compilação essa que, pela colocação desviante das composiçốes, afastadas do bloco das "cantigas de amor", não poderá ter sido senão o Livro das Cantigas do Conde de Barcelos - ver Picchio (1979: 70-71 e n. 4). 


\section{Bibliografia:}

Amado, Teresa (1993). "A cada um a sua Batalha de Tarifa». In Actas do IV Congresso da Associação Hispânica de Literatura Medieval, Aires A. Nascimento e Cristina A. Ribeiro (eds.), vol. 4, pp. 303-307. Lisboa: Cosmos.

Alvar, Carlos e Sarah Finci (2007). «Libro de los estados» (edição crítica). In Don Juan Manuel: Obras Completas, Carlos Alvar e Sarah Finci (eds.), pp. 441-707. Alcalá: Fundación José Antonio de Castro.

Armistead, Samuel G. (2000). La Tradición Épica de las Mocedades de Rodrigo. Salamanca: Ediciones Universidad de Salamanca.

Bautista, Francisco (2006). «Pseudo-historia y leyenda en la historiografia medieval: la Condesa Traidora». In El Relato Historiográfico: Textos y Tradiciones en la España Medieval, Francisco Bautista (ed.), pp. 59-101. London: Medieval Hispanic Research Seminar.

— (2010). "Original, versiones e influencia del Liber regum: estudio textual y propuesta de stemma», e-Spania, 9 [revista on-line]. URL: http://e-spania.revues.org/19884. [Consultado a 2/10/2010].

Bishko, Charles Julian (1975). «The Spanish and Portuguese Reconquest, 1095-1492». In A History of the Crusades, Kenneth M. Settton (ed.), vol. III: The Fourteenth and Fifteenth Centuries, Harry W. Hazard (ed.), pp. 396-456. Madison: University of Wisconsin Press.

Catalán, Diego (1962). De Alfonso X al Conde de Barcelos. Cuatro estudios sobre el nacimiento de la historiografía romance en Castilla y Portugal. Madrid: Gredos.

- (2005). "Rodericus» Romanzado en los reinos de Aragón, Castilla y Navarra (com a colaboração de Enrique Jerez). Madrid: Fundación Ramón Menéndez Pidal.

- e María Soledad de Andrés (1970). Edición Crítica del Texto Español de la Crónica de 1344 que Ordenó el Conde de Barcelos don Pedro Alfonso. Madrid: Gredos/Fundación Ramón Menéndez Pidal.

Cintra, Luís Filipe Lindley (1950a) "O Liber Regum e outras fontes do Livro das Linhagens do Conde D. Pedro». In Miscelânea de Filologia, Literatura e História Cultural à Memória de Francisco Adolfo Coelho, vol. II (Boletim de Filologia, 11, pp. 224-251). Lisboa: Centro de Estudos Filológicos.

— (1950b). «Uma tradução galego-portuguesa desconhecida do Liber Regum». Bulletin Hispanique, 52, pp. 27-40.

- (1951). Crónica Geral de Espanha de 1344, vol. I (Introdução). Lisboa: Academia Portuguesa de História/ Imprensa Nacional Casa da Moeda.

- (1954), Crónica Geral de Espanha de 1344, vol. II (edição crítica). Lisboa: Academia Portuguesa de História/ Imprensa Nacional Casa da Moeda.

- (1961). Crónica Geral de Espanha de 1344, vol. III (edição crítica). Lisboa: Academia Portuguesa de História/Imprensa Nacional Casa da Moeda.

- (1990). Crónica Geral de Espanha de 1344, vol. IV (edição crítica). Lisboa: Academia Portuguesa da História/Imprensa Nacional Casa da Moeda. 
Deswarte, Thomas (2003). De la destruction à la restauration: l'idéologie du royaume d'Oviedo-León (VIII'-XI' siècles). Turnhout: Brepols.

Dias, Isabel Barros (2003). Metamorfoses de Babel. A Historiografia Ibérica (Sécs. XIII-XIV): Construçôes e Estratégias Textuais. Lisboa: Fundaçấo Calouste Gulbenkian/FCT.

Doubleday, Simon R. (2004). Los Lara: Nobleza y monarquia en la España medieval (trad. de Salustiano Masó). Madrid: Turner.

Escalona, Julio (2000). «Épica, crónicas y genealogías en torno a la historicidad de la Leyenda de los Infantes de Lara», Cahiers de Linguistique Hispanique Médiévale, 23, pp. 113-155.

— (2004) «Family Memories: Inventing Alfonso I of Asturias». In Building Legitimacy. Political Discourses and Forms of Legitimacy in Medieval Societies, Isabel Alfonso, Hugh Kennedy e Júlio Escalona (eds.), pp. 223-262. Leiden-Boston: Brill.

Erdmann, Karl (1940). A ideia de Cruzada em Portugal. Coimbra: Imprensa da Universidade de Coimbra.

Fernández-Ordóńez, Inés (2000). «Variación en el modelo historiográfico alfonsí en el siglo XIII. Las versiones de la Estoria de España». In La historia alfonsi: el modelo y sus destinos (siglos XIII-XIV), George Martin (ed.), pp. 41-74. Madrid: Casa de Velásquez.

- (2008). «Transmisión y metamorfosis de los textos en lengua vulgar en la Edad Media: hacia una tipología de mecanismos evolutivos». Conferência plenária apresentada ao II Congresso Internacional da Sociedad de Estudios Medievales y Renacentistas, San Millán de la Cogolla, 10 a 13 de Setembro de 2008 (em curso de publicação nas respectivas actas). Disponível video on-line integral da conferência em http://www.cilengua.es/index.asp?pagina_e=video\&cat=83\&video=139. [Consultado a 10/11/2009].

Ferreira, Maria do Rosário (1998). «Outros Mundos, Outras Fronteiras: Ramiro, Tristão e a divisão da terra de Espanha». Revista da Faculdade de Letras [da Universidade do Porto] - História, II série, 15, pp. 1567-1579. — (2005). A lenda dos Sete Infantes: Arqueologia de um destino épico medieval (Dissertação de Doutoramento apresentada à Faculdade de Letras da Universidade de Coimbra, policopiada).

— (2009). «Terra de Espanha: A Medieval Iberian Utopia». Portuguese Studies, 25(2), pp. 182-198.

— (2010). «O Liber Regum e a representação aristocrática da Espanha pelo Conde D. Pedro de Barcelos». e-Spania, 9 [revista on-line]. URL: http://e-spania.revues.org/19675. [Consultado a 2/07/2010].

Gomes, Joana (2007). As Condessas traidoras e a Terra de Espanha (Dissertaçấo de Mestrado apresentada à Faculdade de Letras da Universidade do Porto, policopiada).

González Jiménez, Manuel (2002). «Sobre la ideología de la Reconquista: realidades y tópicos». In Memoria, Mito y Realidad en la Historia Medieval, J. I. Iglésia Duarte (ed.), pp. 151-170. Logrońo: Instituto de Estudios Riojanos.

Krus, Luís (1994). A concepção nobiliárquica do espaço ibérico (1280-1380). Lisboa: Fundação Calouste Gulbenkian/JNICT. 
Ladero Quesada, Miguel Ángel (1993). «Neogoticismus». In Lexicon des Mittelalters, vol. 6, coll. 1090-1091. München et Zürich: Artemis.

Le Morvan, Gaël (2009). «La Chronica naiarensis: d’un néo-gothisme astur-léonais à un néo-gothisme castillan». e-Spania, 7 [revista on-line]. URL: http://e-spania.revues.org/index18028.html. [Consultado a $10 / 11 / 2009]$.

- (2010). «Le concept de tierra espagnole et le néo-wisigothisme dans le Liber regum». e-Spania, 9 [revista on-line]. URL: http://e-spania.revues.org/19830. [Consultado a 2/07/2010].

Lorenzo, Ramón (1975). La traducción gallega de la Crónica General y de la Crónica de Castilla (edição crítica). Orense: Instituto de Estudios Orensanos «Padre Feijóo».

Martin, Georges (1984). «La chute du Royaume Visigothique d'Espagne dans l'historiographie chrétienne des VIIIe et IXe siècles». Cahiers de Linguistique Hispanique Médiévale, 9, pp. 207-233.

- (1992). Les Juges de Castille. Mentalités et discours historique dans l'Espagne médiévale. Paris: Klincksieck.

- (2001). «Dans l'atelier des faussaires: Lucas, Rodrigo, Alfonso, Sancho...». Cahiers de Linguistique et de Civilisation Hispanique Médiévale, 24, pp. 279-309.

Mattoso, José (1980). Portugaliae Monumenta Historica. Nova Série, vol. II/1: Livro de Linhagens do Conde D. Pedro (edição crítica). Lisboa: Academia de Ciências de Lisboa.

- (1993). História de Portugal, vol. I: Antes de Portugal. Lisboa: Editorial Estampa.

— (1999). «A transmissão textual dos livros de linhagens». In Lindley Cintra. Homenagen ao Homem, ao Mestre e ao Cidadão, Isabel Hub Faria (org.), pp. 565-584. Lisboa: Edições Cosmos.

— (2009). «O triunfo da monarquia portuguesa. Ensaio de história política». In Naquele Tempo, pp. 515-542. Lisboa: Círculo de Leitores.

— e Joseph Piel (1980). «Livro Velho de Linhagens» (edição crítica). In Portugaliae Monumenta Historica. Nova Série, vol. I: Livros Velhos de Linhagens, pp. 21-60. Lisboa: Academia de Ciências de Lisboa.

Menéndez Pidal (1955). Primera Crónica General de España. 2 voll., Madrid: Gredos.

- (1960). «Repoblación y tradición en la cuenca del Duero». In Enciclopedia Lingüistica Hispânica, vol. I: Antecedentes. Onomástica, pp. XXX-XXXI. Madrid: CSIC.

Miranda, José Carlos (1988). "A “Lenda de Gaia” dos Livros de Linhagens: uma Questão de Literatura?». Revista da Faculdade de Letras [da Universidade do Porto] - Linguas e Literaturas, II série, 5, t. II, pp. 483-515.

- (2009a). "A Introdução à Versão Galego-Portuguesa da Crónica de Castela (A2a): Fontes e estratégias». In Seminário Medieval 2007-2008, M. R. Ferreira, J. C. R. Miranda e A. S. Laranjinha (eds.), pp. 61-97. Porto: Estratégias Criativas. URL: http://www.seminariomedieval.com/guarecer/sm0809/A2aNET\%5Bd efinitivo_11.08\%5D\%5B1\%5D.pdf. [Consultado a 10/11/2009].

— (2009b). «Do Liber Regum ao Livro Velho de Linhagens» (a publicar em Seminário Medieval 2009). URL: http:// www.seminariomedieval.com/MIRANDA_DO_LR_aoLVL\%5B1\%5D.pdf. [Consultado a 23/12/2009]. 
- (2010). «Do Liber Regum em Portugal antes de 1340». e-Spania, 9 [revista on-line]. URL: http://e-spania. revues.org/19315. [Consultado a 2/07/2010].

O’Callaghan, Joseph F. (2003). Reconquest and Crusade in Medieval Spain. Philadelphia: University of Pennsylvania Press.

Picchio, Luciana Stegagno (1979). «As cantigas de amor de Vidal, judeu de Elvas». In A Lição do Texto (trad. Alberto Pimenta), pp. 67-93. Lisboa: Ediçôes 70.

Ramos, Manuel Francisco (1996). Memoria de victoria christianorum (Salado-1340) (Dissertação de Mestrado apresentada à Faculdade de Letras da Universidade de Coimbra, policopiada).

Ruiz-Doménec, José Enrique (1984). La memoria de los feudales. Barcelona: Argot.

Saraiva, António José (1971). «O autor da narrativa da batalha do Salado e a refundição do Livro do Conde D. Pedro». Boletim de Filologia, 22, pp. 1-16.

Sousa, Bernardo Vasconcelos e (2005). D. Afonso IV. Lisboa: Círculo de Leitores.

Tarrío, Ana Maria (2006). «La memoria de los godos en João de Barros». In Actas do IV Congresso Internacional de Latim Medieval Hispânico, A. A. Nascimento e P. F. Alberto (eds.), pp. 889-904. Lisboa: Centro de Estudos Clássicos.

Veiga, A. Botelho da Costa (1940). «Os Nossos Nobiliários Medievais. Alguns elementos para a cronologia da sua elaboração". Anais das Bibliotecas e Arquivos, Série II, 15, pp. 165-193. 